\title{
Caractérisation de bactéries lactiques thermophiles isolées de yaourts artisanaux grecs. II. Souches de Lactobacillus delbrueckii subsp bulgaricus et cultures mixtes avec Streptococcus salivarius subsp thermophilus
}

\author{
A Zourari, MJ Desmazeaud* \\ INRA, Station de Recherches Laitières, 78352 Jouy-en-Josas Cedex, France
}

(Reçu le 13 février 1991; accepté le 6 mai 1991)

\begin{abstract}
Résumé - Dix-sept souches de Lactobacillus delbrueckii subsp bulgaricus ont été comparées sur la base des caractères suivants : acidité titrable, viscosité et quantité d'acétaldéhyde produite au cours de la croissance dans le lait; vitesse maximale d'acidification, $\mathrm{pH}$ et temps auxquels la vitesse maximale d'acidification est observée. Les cinétiques d'acidification ont montré deux comportements différents : des souches qui se caractérisent par des acidités titrables élevées et des vitesses maximales d'acidification faibles (estimées par suivi automatique du $\mathrm{pH}$ ), et des souches qui produisent des acidités titrables plus faibles, mais qui ont des vitesses maximales d'acidification significativement supérieures. Trois lactobacilles ont un caractère épaississant intéressant pour la fabrication des yaourts brassés. La production d'acétaldéhyde varie entre 6,5 et $15 \mathrm{ppm}$. Cette quantité est considérablement réduite après une conservation de 21 jours à $4{ }^{\circ} \mathrm{C}$. L'analyse en composantes principales utilisée a permis de définir des groupes de souches ayant un comportement similaire. Des graphiques sous forme d'étoiles représentant simultanément tous les caractères étudiés, ont confirmé la présence de souches apparentées. Des cultures mixtes d'un lactobacille avec cinq souches différentes de Streptococcus salivarius subsp thermophilus n'ont pas toujours révélé une stimulation de l'activité acidifiante des souches impliquées. La quantité d'acétaldéhyde et la viscosité n'ont pas été stimulées en coculture. Les valeurs élevées de viscosité sont obtenues à des $\mathrm{pH}$ plus bas en coculture par rapport à la culture pure de la souche épaississante du lactobacille.
\end{abstract}

Lactobacillus delbrueckii subsp bulgaricus / acidification / caractère épaississant / analyse en composantes principales / culture mixte

Summary - Characterization of lactic acid bacteria isolated from Greek yogurts. II. Strains of Lactobacillus delbrueckii subsp bulgaricus and mixed cultures with Streptococcus salivarius subsp thermophilus. Seventeen Lactobacillus delbrueckii subsp bulgaricus strains were compared on the basis of their titratable acidity, viscosity, amount of acetaldehyde produced in milk, maximum acidification rate and corresponding time and $\mathrm{pH}$ value. Acidification kinetics showed that strains studied have 2 different behaviors: some of them are characterized by high titratable acidities and low maximum acidification rates based on the $\mathrm{pH}$ measurements, the remaining strains develop lower titratable acidities but their maximum acidification rates are significantly higher. Three strains pro-

\footnotetext{
* Correspondance et tirés à part
} 
duce ropiness in milk and are interesting for stirred yogurt production. Acetaldehyde production ranged between 6.5-15 ppm, but this amount was considerably reduced after storage for $21 d$ at $4^{\circ} \mathrm{C}$. Principal component analysis permitted definition of some groups of strains showing similar behaviour. Star graphics confirmed the existence of closely related strains. Mixed cultures of 1 Lactobacillus and 5 Streptococcus salivarius subsp thermophilus strains did not always reveal stimulation between strains on the basis of titratable acidity kinetics. No stimulation of acetaldehyde production or viscosity was observed in mixed cultures. High viscosity values appear at lower $\mathrm{pH}$ compared with pure cultures of the ropy Lactobacillus strain.

\section{Lactobacillus delbrueckii subsp bulgaricus / acidification / ropiness / principal component analysis / mixed culture}

\section{INTRODUCTION}

Lactobacillus delbrueckii subsp bulgaricus et Streptococcus salivarius subsp thermophilus sont les deux bactéries caractéristiques du yaourt et d'autres laits fermentés similaires. Ces deux germes vont acidifier le lait en synergie jusqu'à un $\mathrm{pH}$ inférieur ou égal à 4 , entraînant ainsi la coagulation du lait fermenté. De plus, le lactobacille participe activement au développement de l'arôme typique du yaourt, grâce à l'action de sa thréonine-aldolase, qui conduit à la synthèse d'acétaldéhyde à partir de la thréonine (Lees et Jago, 1976; Manca de Nadra et al, 1987). Enfin, certaines souches, dites épaississantes, produisent des exopolysaccharides qui augmentent la viscosité du lait au cours de la croissance de ces germes, et améliorent ainsi la texture du yaourt (Cerning et al, 1986). C'est une caractéristique déterminante dans la fabrication des yaourts brassés et des yaourts liquides. II faut aussi mentionner que le lactobacille synthétise exclusivement l'isomère $D(-)$ de l'acide lactique, dont la consommation en grande quantité est déconseillée par les nutritionnistes, car elle peut engendrer des troubles métaboliques graves, en particulier chez des personnes ayant des problèmes de santé (Anonyme, 1983). Par conséquent, il faut éviter une acidification excessive du lait par le lactobacille, en particulier pendant la conservation à basse température («postacidification"), ce qui conduit à un yaourt pas trop acide, qui répond le mieux à la demande des consommateurs français. En résumé, la sélection des souches de $L$ delbrueckii subsp bulgaricus pour la fabrication du yaourt est basée sur leurs propriétés acidifiantes, sur la production de composés d'arôme, sur le caractère épaississant et sur une faible acidification à basse température.

En outre, il ne faut pas oublier que les cultures à yaourt sont des levains mixtes où le lactobacille est associé à $S$ salivarius subsp thermophilus. La sélection doit donc porter à la fois sur des souches et sur des associations des deux bactéries. En règle générale, l'association détermine une synergie. Le lactobacille stimule le streptocoque par les produits de son activité protéolytique (Pette et Lolkema, 1950; Bautista et al, 1966; Desmazeaud et Hermier, 1973; Shankar et Davies, 1978), et il est stimulé par le dioxyde de carbone (Driessen et al, 1982) et l'acide formique (Galesloot et al, 1968; Veringa et al, 1968; Higashio et al, 1978) produits par le streptocoque. Cela dit, des cas d'incompatibilité entre souches ont été également signalés, en raison de la production d'agents antibactériens par l'une des souches, ou de la compétition entre les deux germes pour un substrat li- 
mitant du milieu (Moon et Reinbold, 1974, 1976; Pereira Martins et Luchese, 1988). II convient donc de sélectionner des souches qui soient compatibles.

Après avoir caractérisé, dans un article précédent (Zourari et al, 1991), des souches de $S$ salivarius subsp thermophilus isolées de yaourts artisanaux grecs, nous avons mis à profit les mêmes méthodes d'investigation pour étudier cette fois des souches de $L$ delbrueckii subsp bulgaricus provenant de ces mêmes échantillons. Nous avons complété le travail de caractérisation par l'étude du comportement de quelques associations de souches de ces deux bactéries.

\section{MATÉRIEL ET MÉTHODES}

\section{Souches et conditions de culture}

Dix-sept souches de $L$ delbrueckii subsp bulgaricus isolées à partir de yaourts artisanaux grecs (Zourari, 1991) sont étudiées (tableau I). Les souches ATCC 11842 (souche-type de $L$ delbrueckii subsp bulgaricus, citée comme CNRZ 208), CNRZ 369 et 753 y sont jointes.

\section{Méthodes d'étude}

La méthodologie mise en œuvre précédemment (Zourari et al, 1991) pour la culture, la mesure

Tableau I. Souches de $L$ delbrueckii subsp bulgaricus étudiées et leur origine.

$L$ delbrueckii subsp bulgaricus strains and their origin.

\section{Souches* Origine}

\begin{abstract}
CNRZ 1158 (2), CNRZ 1159 (5),
CNRZ 1182 (3), CNRZ 1183 (5),

CNRZ 1185 (1), CNRZ 1186 (1),

CNRZ 1187 (5), CNRZ 1188 (6),

CNRZ 1193 (4), CNRZ 1194 (4)

CNRZ 1184 (7), CNRZ 1189 (8),

CNRZ 1190 (9), CNRZ 1191 (10),

CNRZ 1192 (11), CNRZ 1195 (7),

CNRZ 1196 (7)
\end{abstract}

CNRZ 208 (ATCC 11842)

CNRZ 369

CNRZ 753

\section{Yaourts artisanaux grecs} région de Hania (Crète)

Yaourts artisanaux grecs, région d'Héraclion (Crète)

Souche-type

Souche utilisée dans la fabrication de yaourt (Pays-Bas)

Culture mixte pour yaourt (Bulgarie)

\footnotetext{
* Entre parenthèses, le numéro de l'échantillon de yaourt à partir duquel la souche a été isolée (Zourari, 1991).

* In parentheses, number of yogurt sample from which strain has been isolated (Zourari, 1991).
} 
de l'acidité titrable, le suivi du pH en continu, la mesure de la viscosité, le dosage de l'acétaldéhyde et, enfin, l'analyse des données concernant les souches de $S$ salivarius subsp thermophilus, est intégralement reprise dans le présent travail. Seul le dosage de l'acétaldéhyde s'effectue après culture dans le lait jusqu'à $\mathrm{pH} 4,5$ $( \pm 0,05)$, au lieu de $\mathrm{pH} 5$ choisi pour les streptocoques.

\section{Cultures mixtes de $\mathrm{S}$ salivarius subsp thermophilus et de L delbrueckii subsp bulgaricus}

Une souche de $L$ delbrueckii subsp bulgaricus (CNRZ 1187) et cinq souches de $S$ salivarius subsp thermophilus sont étudiées en culture associée. Le lactobacille est épaississant, il acidifie bien et il produit une quantité non négligeable d'acétaldéhyde. Les cinq souches de $S$ salivarius subsp thermophilus sont : la souche CNRZ 1197 (acidification et arôme faibles, activité uréasique très faible), la souche CNRZ 1156 (bonne acidification, arôme et activité uréasique moyenne), la souche CNRZ 1157 (bonne acidification, arôme fort, activité uréasique moyenne), la souche CNRZ 1203 (faible acidification, arôme fort, activité uréasique la plus faible) et la souche CNRZ 1209 (très acidifiante, aromatique, activité uréasique la plus forte).

Les cultures sont réalisées dans du lait écrémé UHT (Candia, France) à l'exception des cultures pour le dosage de l'acétaldéhyde, qui sont effectuées dans de la poudre de lait reconstitué (Zourari et al, 1991). Le taux d'inoculation est de $5 \%$ en culture pure, et de $2,5 \%$ en culture mixte, pour chacune des souches utilisées. Dans le cas des cultures destinées au dosage de l'acétaldéhyde, ces taux sont respectivement de 3 et $1,5 \%$.

Au cours de la croissance, l'évolution de l'acidité titrable (acidité acquise) est suivie, ainsi que celle du $\mathrm{pH}$ (avec un $\mathrm{pH}$ mètre PHN 81, Tacussel, France). Le dénombrement des streptocoques et des lactobacilles est effectué par numération directe sous le microscope, selon la méthode de Breed (Sharf, 1966), après dilutions décimales et coloration des cellules au bleu de méthylène. La viscosité est suivie à partir de $\mathrm{pH}$ 5. L'acétaldéhyde produit est mesuré à pH 4,7 \pm
0,05 . À ce même $\mathrm{pH}$, un échantillon est placé à $4{ }^{\circ} \mathrm{C}$ pendant 21 jours, pour doser l'acétaldéhyde et mesurer le $\mathrm{pH}$ atteint à la fin de la conservation.

\section{RÉSULTATS}

\section{Acidification}

\section{Acidité titrable acquise}

Après $3 \mathrm{~h}$ d'incubation, 3 souches (dont la souche de collection CNRZ 369) produisent plus de $0,3 \%$ d'acide lactique, les 15 autres en produisant bien moins de $0,25 \%$ (fig 1). Après $7 \mathrm{~h}$ d'incubation, 8 souches produisent des acidités titrables supérieures à $0,5 \%$ d'acide lactique, 7 souches entre 0,4 et $0,5 \%$, tandis que les acidités de 3 souches restent inférieures à $0,4 \%$. II s'avère alors que selon le temps d'incubation choisi, la distribution des souches est différente, apparemment à cause de différentes vitesses d'acidification. II en est de même pour les valeurs d'acidité développées après $24 \mathrm{~h}$ d'incubation : les souches qui acidifient le plus ne sont pas celles qui développent les acidités les plus élevées aux temps d'incubation les plus courts.

\section{Suivi du pH}

Le suivi du $\mathrm{pH}$ en continu au cours de la croissance des lactobacilles permet de définir une vitesse d'acidification ( $\mathrm{dpH} / \mathrm{dt}$ ) maximale $(V m)$ à un temps ( $T m$; fig $2 a)$ et à un $\mathrm{pH}(\mathrm{pH}$; fig $2 \mathrm{~b})$ déterminés.

Deux groupes de souches sont facilement distingués (fig 3 ) sur la base de leurs $\mathrm{Vm}, \mathrm{Tm}, \mathrm{pHm}, \mathrm{T50}$ et $\mathrm{pH} 50$. Le premier groupe est composé de 5 souches (CNRZ $1191,1193,1194$ et 1196 , et la souche type CNRZ 208), caractérisées par une valeur de $\mathrm{Vm}$ faible $\left(5,8\right.$ à $\left.7 \mathrm{mU} \mathrm{pH} \cdot \mathrm{min}^{-1}\right)$, 


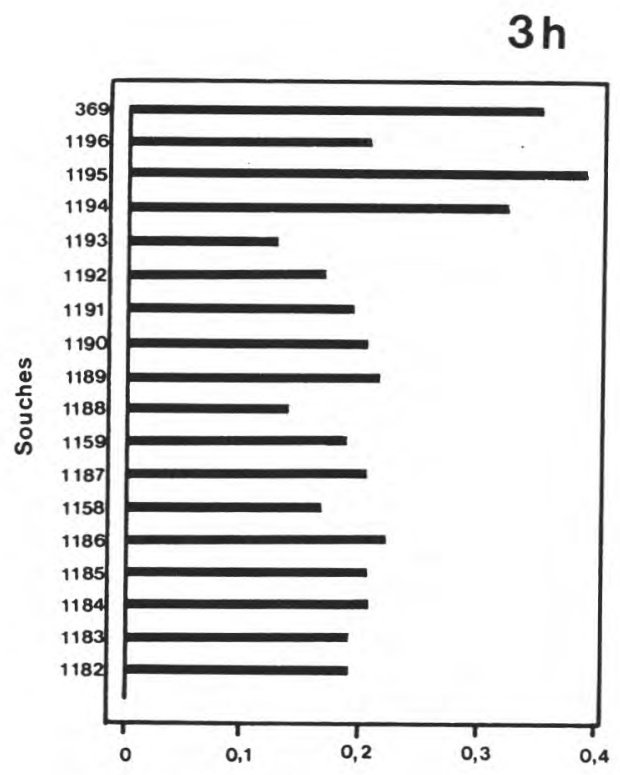

Acidité titrable ( $\%$ acide lactique)

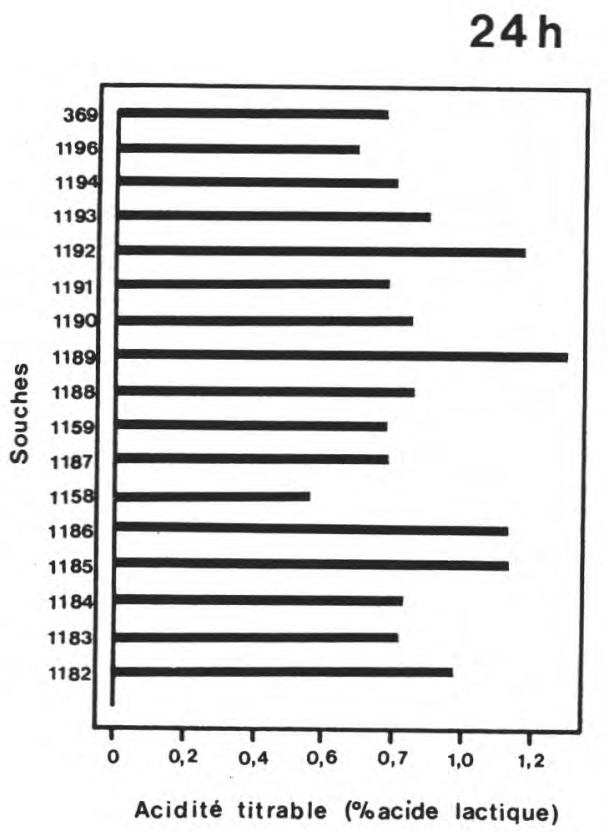

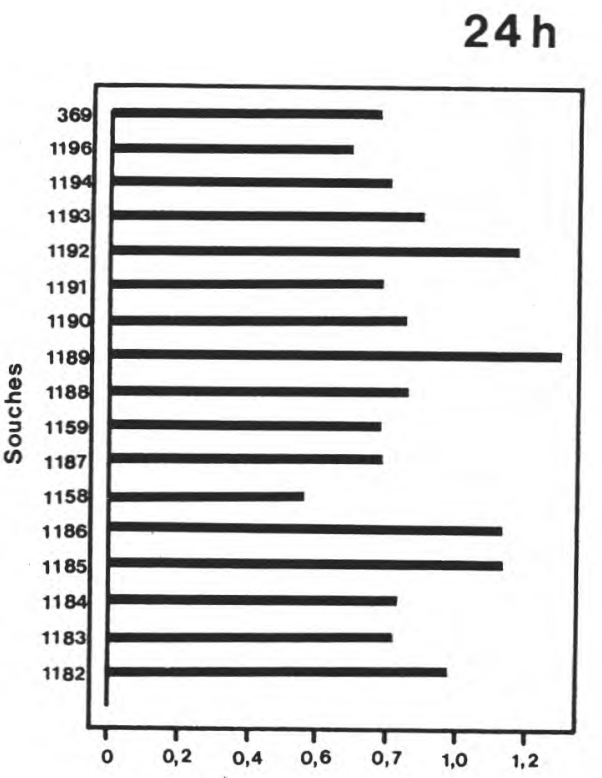

Acidité titrable ( $\%$ acide lactique)
$7 \mathrm{~h}$

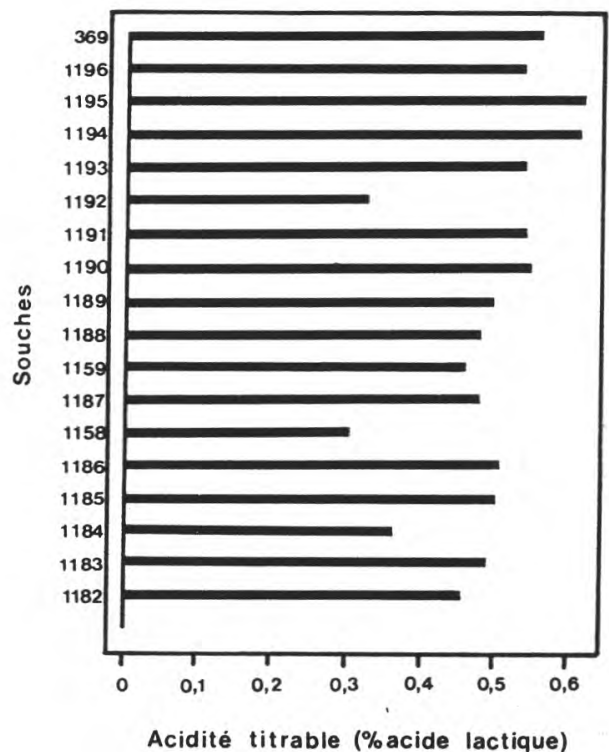

Acidité titrable (\%acide lactique)
Fig 1. Valeurs de l'acidité titrable acquise développée après 3,7 et $24 \mathrm{~h}$ d'incubation dans le lait, à $42{ }^{\circ} \mathrm{C}$, par les souches de $L$ delbrueckii subsp bulgaricus. Quand une valeur n'est pas déterminée, la souche correspondante n'apparaît pas sur la figure.

Acquired titratable acidity after 3, 7 and $24 \mathrm{~h}$ incubation in milk at $42{ }^{\circ} \mathrm{C}$ for $\mathrm{L}$ delbrueckii subsp bulgaricus strains. If acidity has not been determined the corresponding strains are not presented in the graphics. 


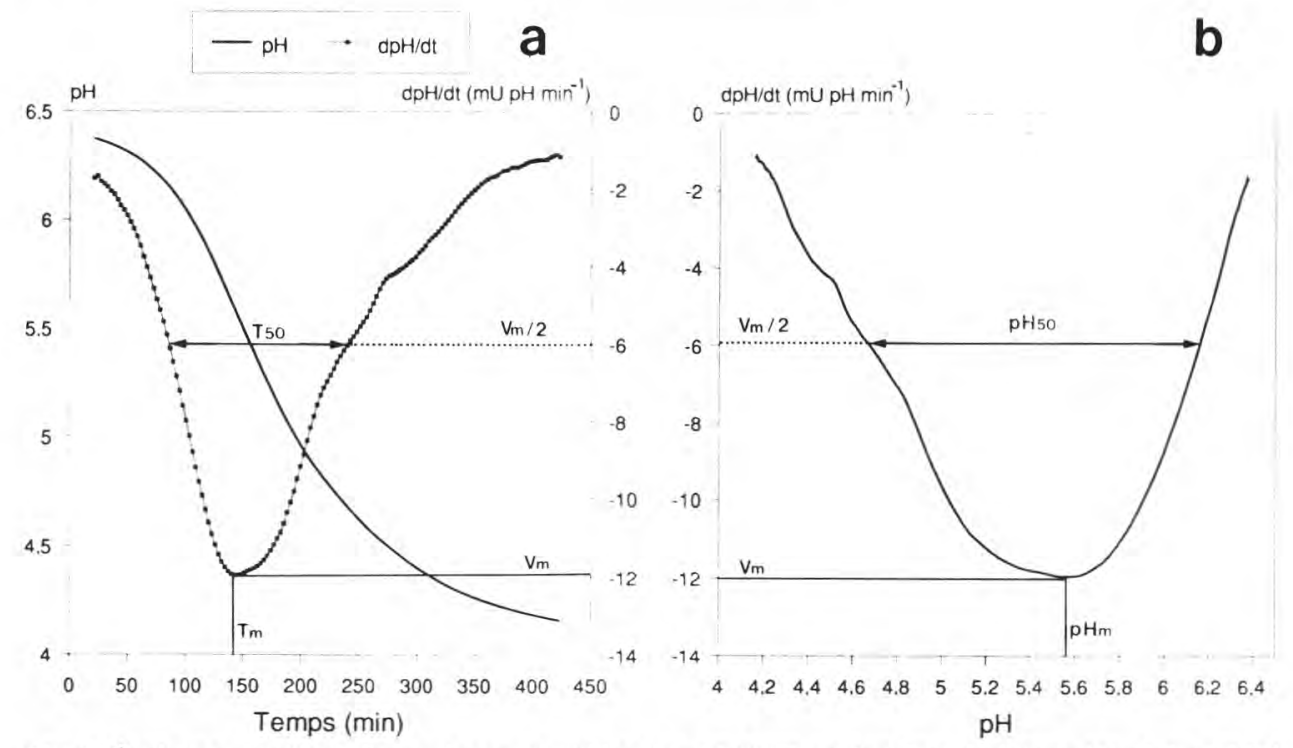

Fig 2. Évolution du pH et de la vitesse d'acidification (dpH/dt) en fonction du temps (a) et du pH (b) pour la souche CNRZ 1195, caractéristique des souches de L delbrueckii subsp bulgaricus. $\mathrm{pH}$ and acidification rate (dpH/dt) kinetics versus time (a) and $\mathrm{pH}$ (b) for strain CNRZ 1195, characteristic for $L$ delbrueckii subsp bulgaricus strains.

tandis que les valeurs de $T m$ et de $T 50$ sont très élevées (280 à $430 \mathrm{~min}$ pour $T 50$ et 174 à $241 \mathrm{~min}$ pour $\mathrm{Tm}$ ). Le second groupe comprend 13 souches. Leurs valeurs de $V m$ sont plutôt élevées (entre 9,8 et 13,7 $\mathrm{mU} \cdot \mathrm{min}^{-1}$ ), les souches CNRZ 1189 et 1192 ayant les valeurs les plus fortes (entre 13 et $14 \mathrm{mU} \mathrm{pH} \cdot \mathrm{min}^{-1}$ ). Les valeurs de $\mathrm{Tm}$ sont nettement plus faibles que celles du premier groupe (123 à 171 $\mathrm{min}$ ), ainsi que celles de T50 (120 à 190 min). Les valeurs de $\mathrm{pHm}$ et de $\mathrm{pH} 50$ ne permettent pas de bien délimiter les 2 groupes. Enfin, le premier groupe, celui des faibles valeurs de $V m$ comprend des souches qui produisent, après $7 \mathrm{~h}$ d'incubation, des acidités titrables parmi les plus élevées.

\section{Post-acidification}

Après 21 jours à $4^{\circ} \mathrm{C}$, les lactobacilles étudiés réduisent le $\mathrm{pH}$ au plus de 0,6 unité (souches CNRZ 1191 et 208), qu'ils soient conservés à pH initial 4,7 ou 4,5 .

\section{Viscosité développée}

La majorité des souches développent, à $\mathrm{pH} 5$, une viscosité située entre 40 et 50 $\mathrm{mPa} \cdot \mathrm{s}$. Les souches CNRZ 1187, 1159 et 1191 donnent des valeurs plus élevées, voisines de 145, 105 et $95 \mathrm{mPa} \cdot \mathrm{s}$ respectivement. Ces mêmes souches, à $\mathrm{pH} 4,5$, donnent des viscosités d'environ 160, 135 et $120 \mathrm{mPa} \cdot \mathrm{s}$ respectivement, contre 50 à 
Représentation des variables $\mathrm{V}_{\mathrm{m}}, \mathrm{pH}$ et $\mathrm{Tm}$

$\operatorname{Tm}(\min )$

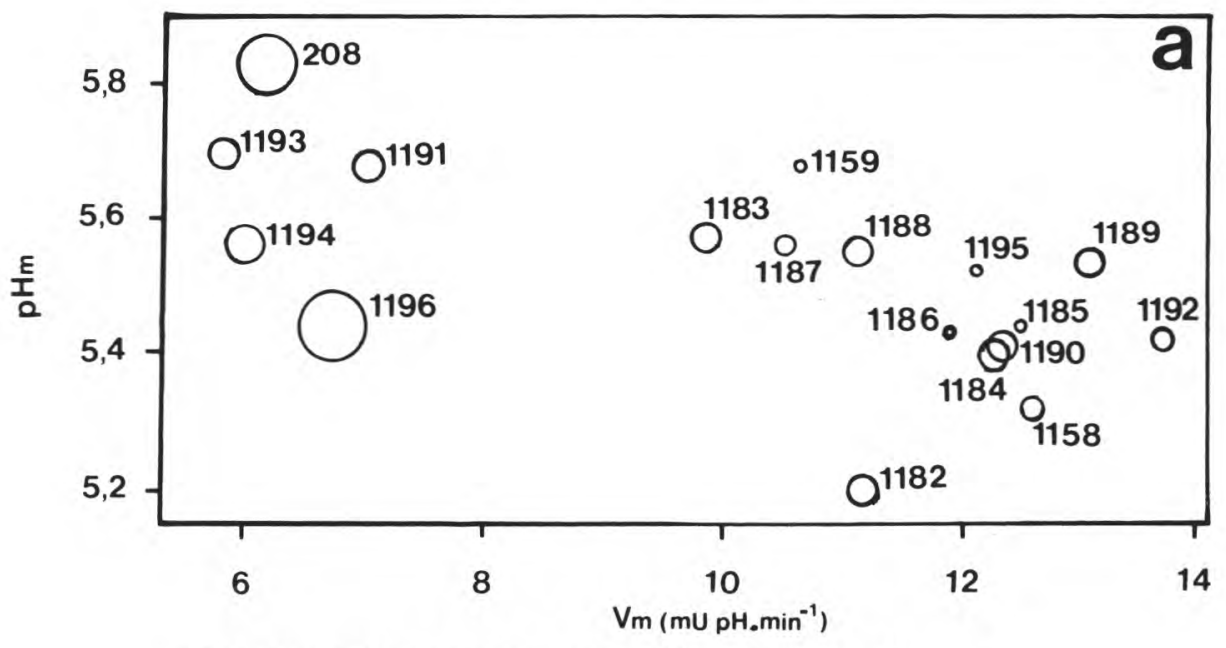

Représentation des variables $\mathrm{Vm}_{\mathrm{m}}, \mathrm{pH}_{\mathrm{m}}$ et $\mathrm{T}_{50}$

T50(min)

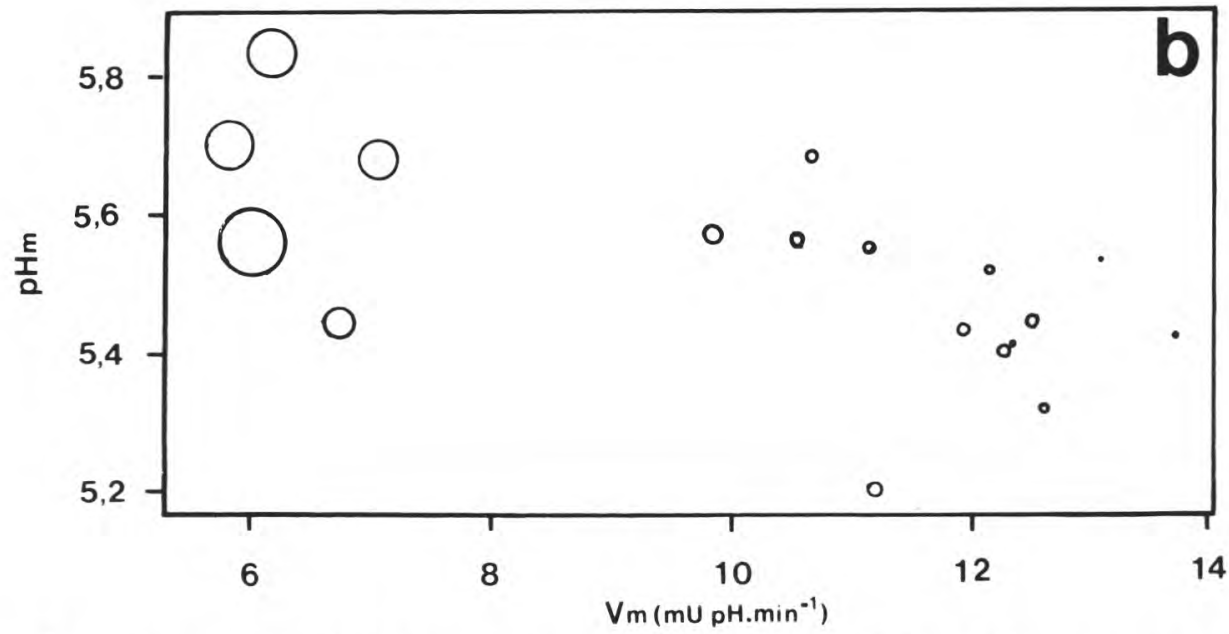

Fig 3. Représentation graphique simultanée des variables $\mathrm{Vm}$, pHm et $\mathrm{Tm}$ ou $\mathrm{T} 50$, estimées pour les souches de $L$ delbrueckii subsp bulgaricus. Les points correspondant à $V m$ et $p H m$ sont les centres des cercles dont les rayons sont proportionnels à la valeur du T50. Chaque point représente une souche (donnée par son numéro CNRZ). Tm: temps pour lequel la vitesse maximale d'acidification est observée; T50: temps pendant lequel la vitesse d'acidification est supérieure à la moitié de sa valeur maximale.

Simultaneous presentation of $\mathrm{Vm}, \mathrm{pHm}$ and $\mathrm{Tm}$ or $\mathrm{T} 50$ for $\mathrm{L}$ delbrueckii subsp bulgaricus strains. Points corresponding to $\mathrm{Vm}$ and $\mathrm{pH}$ are the circle centres the radius of which are proportional to $\mathrm{Tm}$ or T50 value. Every point corresponds to one strain (given as CNRZ numbers). Tm: time corresponding to Vm; T50: time during which the observed acidification rate is higher than half of its maximum value. 
$85 \mathrm{mPa} \cdot \mathrm{s}$ pour les autres souches. Après 21 jours à $4^{\circ} \mathrm{C}$, la viscosité varie peu.

\section{Production d'acétaldéhyde}

Les 17 souches isolées des yaourts grecs produisent entre 6,5 et 15 ppm d'acétaldéhyde, 6 d'entre-elles dépassant 10 ppm d'acétaldéhyde (15 ppm pour la souche CNRZ 1189). En comparaison, la souche CNRZ 753, considérée comme aromatique, produit $9 \mathrm{ppm}$ d'acétaldéhyde, et la souche-type CNRZ 208 en produit seulement 5 ppm.

Après conservation à $4{ }^{\circ} \mathrm{C}$, la quantité d'acétaldéhyde diminue considérablement, les valeurs obtenues se situant entre 4 et $10,5 \mathrm{ppm}$ et même à moins de $1 \mathrm{ppm}$ pour la souche type.

\section{Analyse des données}

Après le calcul des coefficients de corrélation entre les différentes variables et la représentation graphique par paires de ces dernières (fig 4 , pour les variables rela- tives à l'acidification du lait), une analyse en composantes principales (ACP) permet de classer les souches, en tenant compte de tous les caractères étudiés.

\section{Relations entre variables}

\section{Variables relatives à l'acidification}

La totalité des observations obtenues pendant les deux répétitions du suivi du $\mathrm{pH}$ est utilisée (graphiques et tableaux non présentés), parallèlement aux valeurs moyennes caractérisant les souches. Des représentations graphiques par paires des variables (fig 4) sont réalisées comme complément du calcul des coefficients de corrélation (tableau II), pour mettre en évidence les relations éventuelles entre les variables. Ces graphiques sont intéressants parce qu'ils permettent de détecter également l'existence d'une relation étroite non linéaire entre les variables (qui ne conduit pas à des coefficients de corrélation élevés), la présence de groupes de souches qui ont un comportement similaire ou la présence de souches particulières, ce qui peut modifier la valeur des coeffi-

Tableau II. Coefficients de corrélation estimés pour les variables relatives à l'acidification du lait pour les souches de $L$ delbrueckii subsp bulgaricus. $A T$ : acidité titrable; $d p H$ : réduction du pH après 21 jours à $4{ }^{\circ} \mathrm{C}$ (a : $\mathrm{pH}$ initial de $4,5 / \mathrm{b}: \mathrm{pH}$ initial de 4,7$)$.

Correlation coefficient estimated for variables related to milk acidification by $\mathrm{L}$ delbrueckil subsp bulgaricus strains. AT: titratable acidity; dpH: $p H$ reduction after 21 days at $4{ }^{\circ} \mathrm{C}$ (a: initial $p H 4.5 / b$ : initial pH 4.7).

\begin{tabular}{|c|c|c|c|c|c|c|c|c|}
\hline \multirow{9}{*}{$\begin{array}{l}\text { pHm } \\
\text { T50 } \\
\text { pH50 } \\
\text { Tm } \\
\text { AT7h } \\
\text { AT24h } \\
\text { dpH1 } \\
\text { dpH2 }\end{array}$} & $-0,54$ & & & & & & & \\
\hline & $-0,94$ & 0,45 & & & & & & \\
\hline & $-0,64$ & 0,13 & 0,74 & & & & & \\
\hline & $-0,64$ & $-0,03$ & 0,55 & 0,23 & & & & \\
\hline & $-0,66$ & 0,46 & 0,63 & 0,32 & 0,35 & & & \\
\hline & 0,45 & $-0,11$ & $-0,33$ & $-0,19$ & $-0,39$ & 0,04 & & \\
\hline & $-0,10$ & 0,18 & 0,06 & 0,27 & $-0,10$ & $-0,01$ & $-0,08$ & \\
\hline & 0,38 & $-0,22$ & $-0,31$ & 0,12 & $-0,47$ & $-0,44$ & $-0,20$ & 0,23 \\
\hline & $V m$ & $p H m$ & T50 & $\mathrm{pH} 50$ & $\mathrm{Tm}$ & AT7h & AT24h & $d p H_{a}$ \\
\hline
\end{tabular}



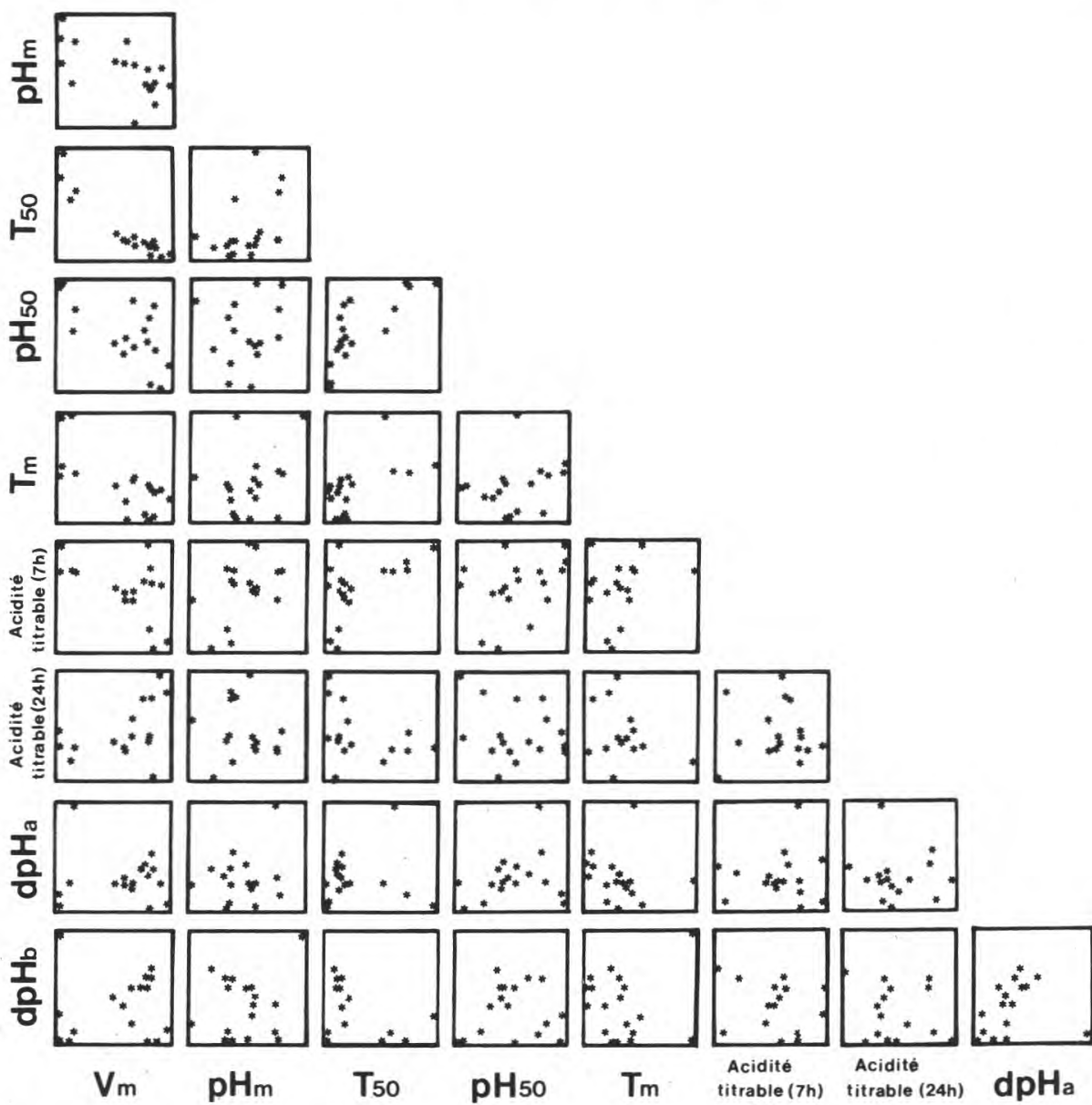

Fig 4. Représentation graphique par paires des variables relatives à l'acidification du lait par les souches de $L$ delbrueckii subsp bulgaricus. Les valeurs utilisées sont les moyennes de 2 répétitions. $d p H$ : chute du $\mathrm{pH}$ après conservation à $4{ }^{\circ} \mathrm{C}$ pendant 21 jours $(d p H a$ : à $\mathrm{pH}$ initial de 4,$5 ; d p H b$ : à pH initial de 5).

Pair graphics of variables related to milk acidification by $L$ delbrueckii subsp bulgaricus strains using the mean values of 2 assays. $\mathrm{dpH}: \mathrm{pH}$ reduction after storage at $4{ }^{\circ} \mathrm{C}$ for $21 \mathrm{~d}$ (dpHa : initial $\mathrm{pH} 4.5$; $\mathrm{dpHb}$ : initial $\mathrm{pH} 5)$.

cients de corrélation. Les variables relatives au suivi automatique du $\mathrm{pH}$ sont peu corrélées entre elles, à l'exception d'une forte corrélation négative entre $\mathrm{Vm}$ et $\mathrm{T50}$.
La chute du pH à basse température ou l'acidité titrable développée après $7 \mathrm{~h}$ ou 24 h n'apparaît pas corrélée avec les variables estimées par le suivi du $\mathrm{pH}$. 


\section{Variables relatives à la viscosité}

II y a une forte corrélation entre les différentes mesures de viscosité ( $r$ entre 0,90 et 0,94$)$, mais non entre celles-ci et le pH après une conservation de 21 jours à $4{ }^{\circ} \mathrm{C}$ ( $r$ entre $-0,24$ et 0,50 ).

\section{Variables relatives à la production d'acétaldéhyde}

La quantité d'acétaldéhyde produite après culture à $42{ }^{\circ} \mathrm{C}($ à $\mathrm{pH} 4,7)$ et la quantité mesurée après une conservation de 21 jours à $4{ }^{\circ} \mathrm{C}$ sont positivement corrélées $(r=0,72)$. II n'y a pas de corrélation entre ces deux variables et le $\mathrm{pH}$ après conservation à $4{ }^{\circ} \mathrm{C}$.

\section{Analyse en composantes principales}

Les variables $\mathrm{Vm}, \mathrm{pHm}, T \mathrm{~m}$, l'acidité titrable après $7 \mathrm{~h}$ de culture, la viscosité à $\mathrm{pH} 4,5$ et la quantité d'acétaldéhyde produite à $\mathrm{pH} 4,7$ sont retenues pour l'ACP.

Les 3 premiers axes $\left(F_{1}, F_{2}\right.$ et $\left.F_{3}\right)$ expliquent $82 \%$ de la variance. La figure 5 présente la projection du nuage des points correspondant aux souches, sur les plans $F_{1} F_{2}$ et $F_{1} F_{3}$, ainsi que la position de chacune des variables utilisées par rapport aux 3 axes. L'axe $F_{1}$ met en opposition l'acidité titrable après $7 \mathrm{~h}$ d'incubation et $V m$. L'axe $F_{2}$ oppose la viscosité et $T m$. La production d'acétaldéhyde est maximale pour les souches qui se trouvent à l'extrémité de l'axe $F_{3}$.

Sur le plan défini par les axes $F_{1}$ et $F_{2}$ (fig $5 \mathrm{a}$ ) on peut distinguer 4 groupes de souches. Les 7 souches du groupe A constituent un ensemble relativement hétérogène. Elles sont caractérisées par des valeurs de $V m$ et d'acidité titrable moyennes (souches CNRZ 1183 et 1188) ou élevées, et une production d'acétaldé- hyde variable. Ces souches ne sont pas épaississantes.

Les 4 souches du groupe B (CNRZ $1191,1193,1194$ et 1196) se caractérisent par des acidités titrables très élevées et des valeurs de $V m$ très faibles. II s'agit de souches non épaississantes à l'exception de la 1191. La production d'acétaldéhyde est variable.

Le groupe des souches CNRZ 1192, 1158,1184 et 1182 (groupe C) est à l'opposé du groupe précédent : leurs valeurs de $V m$ sont parmi les plus élevées, les acidités titrables parmi les plus faibles, alors que la viscosité et la quantité d'acétaldéhyde produite sont très faibles.

Enfin, les souches CNRZ 1187 et 1159 (groupe D) se situent à part, en raison de leur caractère épaississant. Elles acidifient moyennement, et produisent une quantité importante d'acétaldéhyde. La souche CNRZ 1191, qui est également épaississante, est placée dans le groupe B à cause de ses propriétés d'acidification particulières.

Si l'on considère le plan des axes $F_{1}$ et $\mathrm{F}_{3}$ (fig $5 \mathrm{~b}$ ), les groupes (à l'exception du groupe D) se divisent en 2, en fonction du niveau de la production d'acétaldéhyde des souches. Les souches placées audessus de l'axe $F_{1}$ produisent une quantité importante d'acétaldéhyde, alors que les souches situées au-dessous de cet axe sont moins aromatiques, à l'exception des souches CNRZ 1187 et 1159 qui s'y trouvent à cause de leur caractère épaississant.

Les affinités entre les souches sont mieux illustrées par des représentations graphiques ayant la forme d'étoiles, dont la longueur des branches correspond aux valeurs des différentes variables (fig 6). S'il est admis que deux souches ayant des "étoiles" de forme similaire ont un comportement analogue, le classement obtenu 


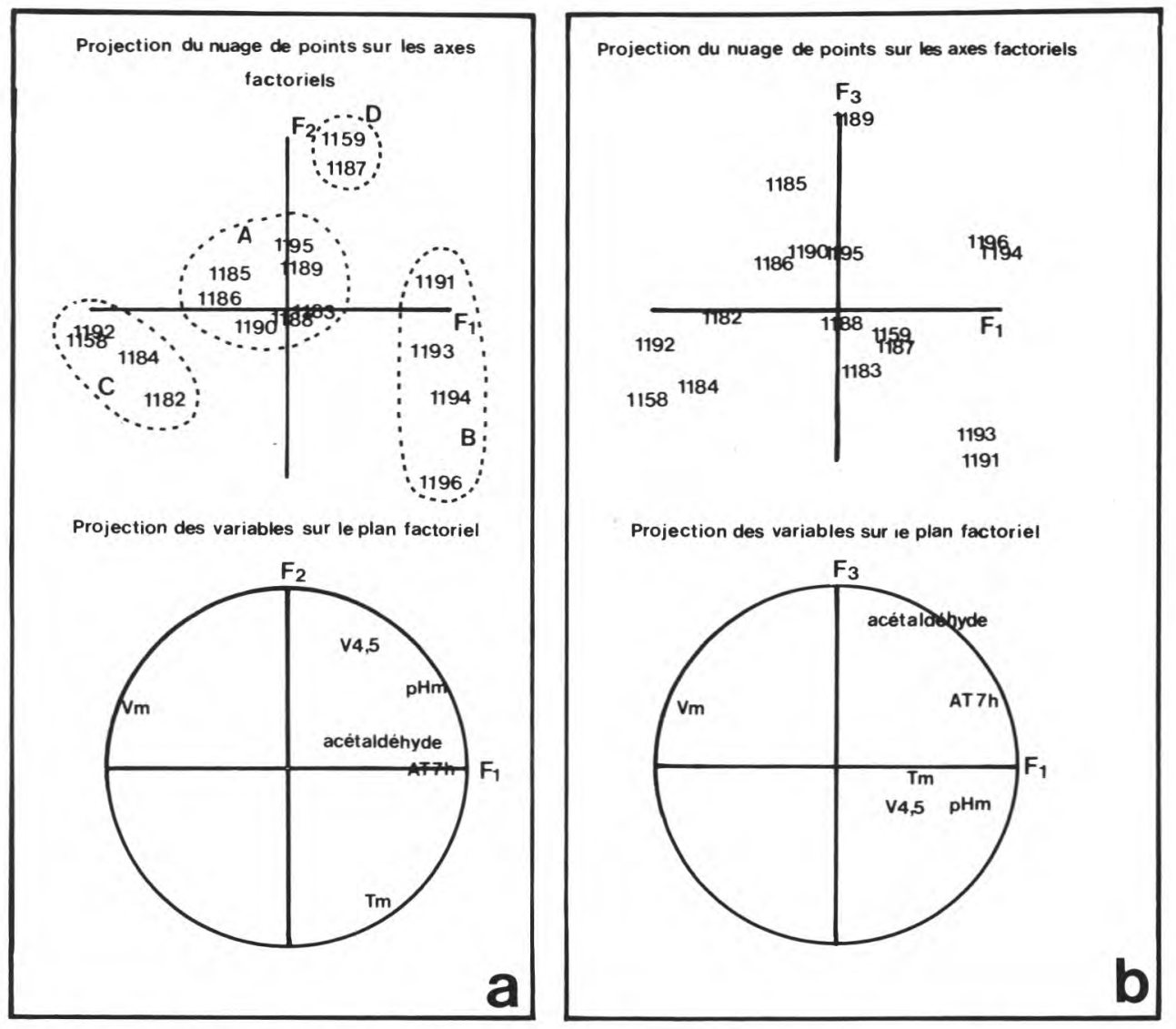

Fig 5. Analyse en composantes principales pour les souches de $L$ delbrueckii subsp bulgaricus. AT: acidité titrable acquise; $V 4,5$ : viscosité à $\mathrm{pH} 4,5$.

Principal component analysis for L delbrueckii subsp bulgaricus strains. AT: acquired titratable acidity; V4.5 : viscosity at $\mathrm{pH} 4.5$.

par l'ACP est reproduit. Ainsi, des similarités se révèlent entre les souches suivantes: CNRZ 1187 et 1159; CNRZ 1185 et 1186; CNRZ 1158, 1184 et 1192; CNRZ 1196 et 1194; CNRZ 1191 et 1193 (la CNRZ 1191 étant épaississante); CNRZ 1183 et 1188 .

\section{Caractérisation des cultures mixtes}

Le comportement de la souche CNRZ 1187 de $L$ delbrueckii subsp bulgaricus est étudié en culture mixte avec 5 souches différentes de streptocoques (CNRZ 1197, $1156,1157,1203$ et 1209). 


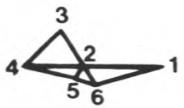

1182

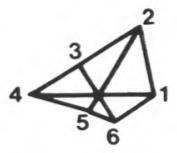

1183

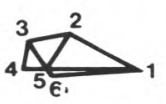

1184

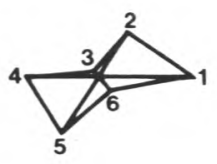

1185

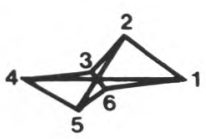

1186

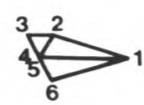

1158

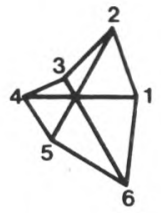

1187

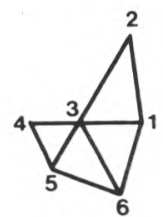

1159

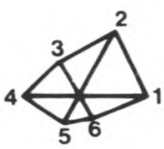

1188

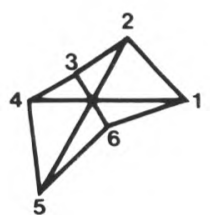

1189

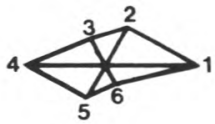

1190

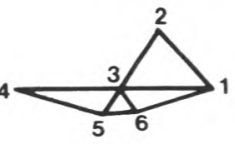

1195

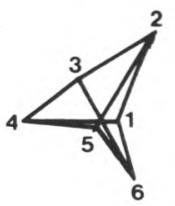

1191

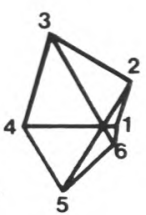

1196

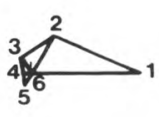

1192

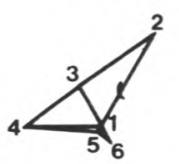

1193

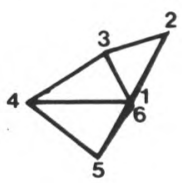

1194

Fig 6. Représentation graphique sous forme d'étoiles des souches de $L$ delbrueckii subsp bulgaricus.

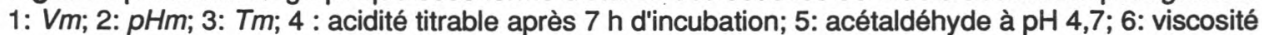
à $\mathrm{pH} 4,5$.

Star graphics for $\mathrm{L}$ delbrueckii subsp bulgaricus strains. 1: Vm; 2: pHm; 3: Tm; 4: titratable acidity after $7 \mathrm{~h}$ incubation; 5: acetaldehyde at $\mathrm{pH} 4.7$; 6: viscosity at $\mathrm{pH} 4.5$. 
L'acidité titrable acquise en culture mixte est comparée avec la somme des acidités produites en culture pure. L'acidité de la culture mixte en début d'incubation (2 à $3 \mathrm{~h}$ ) ne diffère pas de celle produite par le streptocoque en culture pure (fig 7). Par la suite, lorsqu'il existe un effet synergique (fig 7a), l'acidité en culture mixte dépasse la somme des acidités en culture pure. La situation inverse est également observée. Dans le cas des souches CNRZ 1197 et 1203 (deux streptocoques peu acidifiants dont la croissance dans le lait est lente), l'acidité développée en culture mixte est toujours inférieure à la somme des acidités en culture pure (fig $7 b$ ).

La population maximale du lactobacille en coculture augmente de 0,5 à 0,8 unité de log (tableau III). Par contre, les populations maximales de streptocoques atteintes en coculture, sont inférieures à celles des cultures pures de 0,2 à 0,8 unité de log.

L'interprétation des résultats du suivi automatique du $\mathrm{pH}$ est difficile à cause des deux valeurs de $V m$ des streptocoques retrouvées en culture mixte (fig 8). La valeur de $V m_{1}$ en culture mixte est quasi identique à celle de $V m_{1}$ du streptocoque en culture pure (tableau IV). La valeur de $\mathrm{Vm}_{2}$ est proche (souches CNRZ 1197, 1156 et 1203) ou inférieure à celle du streptocoque (souches CNRZ 1209 et 1157). En culture mixte, entre les deux $V m$, la vitesse d'acidification atteint des valeurs plus faibles par rapport à celles des cultures pures de streptocoques et le $\mathrm{pH}$ reste stable plus longtemps ( $d T m$, égal à $T m_{2}-T m_{1}$, plus élevé). La comparaison des valeurs de $d T m$ montre que ce phénomène est plus prononcé pour la souche CNRZ 1209 (fig $8 \mathrm{a})$, qui a l'activité uréasique la plus forte

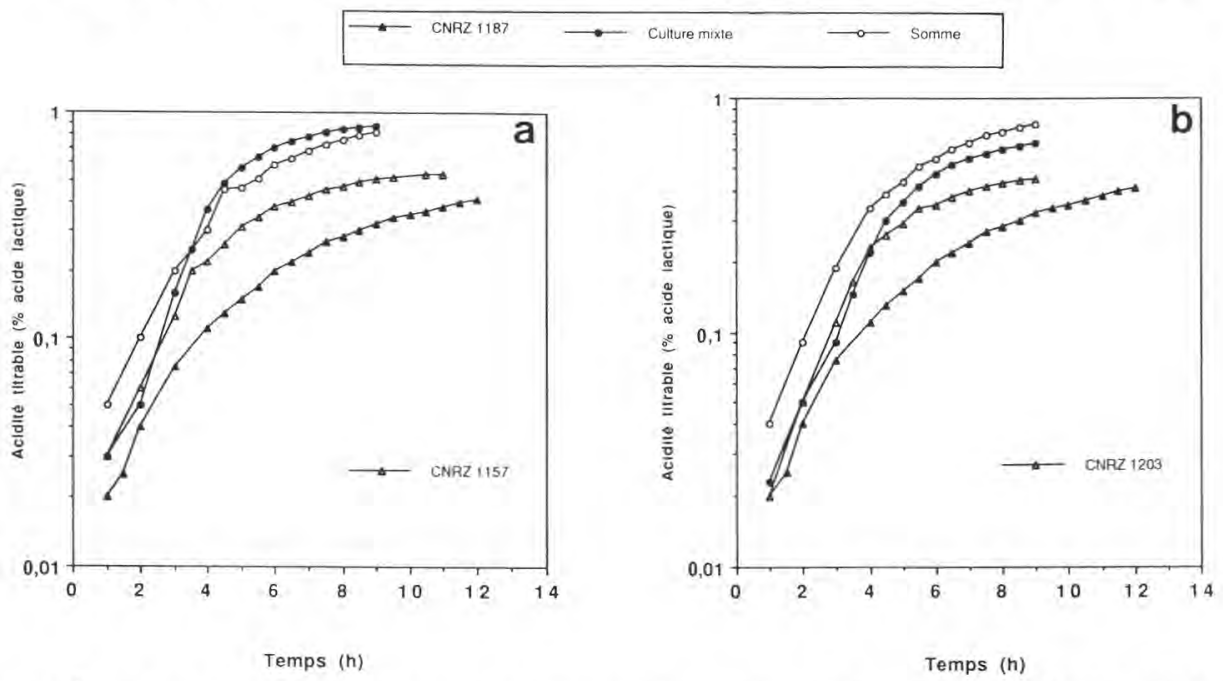

Fig 7. Évolution de l'acidité titrable acquise au cours de la croissance dans le lait $\left(42^{\circ} \mathrm{C}\right)$ des souches $S$ salivarius subsp thermophilus CNRZ 1157 (a) et CNRZ 1203 (b) en culture pure et en association avec la souche $L$ delbrueckii subsp bulgaricus CNRZ 1187. Comparaison de l'acidité titrable en culture mixte avec la somme des acidités développées par les deux souches en culture pure.

Acquired titratable acidity kinetics during growth in milk $\left(42^{\circ} \mathrm{C}\right)$ for $\mathrm{S}$ salivarius subsp thermophilus CNRZ 1157 (a) and CNRZ 1203 (b) in pure culture and associated with L delbrueckii subsp bulgaricus CNRZ 1187. Comparison of titratable acidity in mixed culture with sum of acidities developed in pure culture by both strains. 
Tableau III. Populations maximales $(X m)$ atteintes par les souches de $S$ salivarius subsp thermophilus CNRZ 1197, 1156, 1157, 1203, 1209 et L delbrueckii subsp bulgaricus CNRZ 1187 dans le lait $\left(42{ }^{\circ} \mathrm{C}\right)$, en culture pure et en coculture. $n c$ : nombre de cellules; - : non déterminé; $X m$ pour la souche CNRZ 1187 en culture pure : 0,45 et $0,30 \mathrm{nc} \times 10^{9} \mathrm{ml}^{-1}$.

Maximum cell numbers $(\mathrm{Xm})$ for $\mathrm{S}$ salivarius subsp thermophilus CNRZ 1197, 1156, 1157, 1203, 1209 and $\mathrm{L}$ delbrueckii subsp bulgaricus CNRZ 1187 in milk $\left(42{ }^{\circ} \mathrm{C}\right)$ in pure and mixed culture. nc: cell number; - : not determined; Xm for CNRZ 1187 strain in pure culture: 0.45 and $0.30 \mathrm{nc} \times 10^{9} \mathrm{ml}^{-1}$.

\begin{tabular}{|c|c|c|c|}
\hline \multirow{2}{*}{$\begin{array}{l}\text { Souches } \\
\left(n^{\circ} \mathrm{CNRZ}\right)\end{array}$} & \multicolumn{2}{|c|}{$X m$ (S salivarius subsp thermophilus) } & \multirow{2}{*}{$\begin{array}{c}\text { Xm (L delbrueckii subsp bulgaricus) } \\
\text { Culture mixte } \\
\left.\text { (nc } \times 10^{9} \mathrm{ml}^{-1}\right)\end{array}$} \\
\hline & $\begin{array}{c}\text { Culture pure } \\
\left(\mathrm{nc} \times 10^{9} \mathrm{mt}^{-1}\right)\end{array}$ & $\begin{array}{r}\text { Culture mixte } \\
\left(\mathrm{nc} \times 10^{9} \mathrm{~m}^{-1}\right)\end{array}$ & \\
\hline \multirow{3}{*}{1197} & - & 0,45 & 0,80 \\
\hline & 0,70 & 0,45 & 0,55 \\
\hline & - & 0,45 & 0,65 \\
\hline \multirow[t]{2}{*}{1156} & 1,35 & 0,50 & 1,30 \\
\hline & 1,60 & 0,50 & 0,95 \\
\hline \multirow[t]{2}{*}{1203} & 1,20 & 0,30 & 1,55 \\
\hline & 1,05 & 0,35 & 1,00 \\
\hline \multirow[t]{2}{*}{1157} & 2,25 & 0,70 & 1,70 \\
\hline & 2,55 & 0,45 & 1,60 \\
\hline \multirow[t]{2}{*}{1209} & 0,80 & 0,65 & 2,20 \\
\hline & 1,50 & 0,65 & 2,45 \\
\hline
\end{tabular}

et qui, associée avec le lactobacille, développe une synergie évidente sur la base de l'évolution de l'acidité titrable. Le contraire est observé pour la souche CNRZ 1197, qui a une activité uréasique moyenne, et qui n'entraîne pas d'effet synergique en coculture avec le lactobacille (fig 8b). Les 3 autres souches de streptocoques (CNRZ 1156, 1157 et 1203) occupent des positions intermédiaires selon leur activité uréasique et leurs interactions avec la souche CNRZ 1187.

II n'y a pas de stimulation de la production d'acétaldéhyde en culture mixte, par rapport à celle que produit le lactobacille seul (entre 10 et 13 ppm à pH 4,7 dans les deux cas).
Le suivi de la viscosité au cours de la croissance montre que les fortes valeurs de viscosité sont observées à des $\mathrm{pH}$ plus bas que dans le cas de la culture du lactobacille seul. Cela résulte de la croissance plus tardive du lactobacille, qui ne survient qu'après que le streptocoque ait déjà sensiblement abaissé le $\mathrm{pH}$ du lait. Les valeurs de viscosité atteintes en culture mixte sont équivalentes à celles obtenues en culture pure.

\section{DISCUSSION}

Le premier rôle des bactéries lactiques étant d'acidifier le lait, leur activité acidi- 
Tableau IV. Valeurs des $\mathrm{Vm}$, pHm et $\mathrm{Tm}$ estimées par le suivi du $\mathrm{pH}$ dans le lait $\left(42^{\circ} \mathrm{C}\right)$, pour les souches de $S$ salivarius subsp thermophilus et de $L$ delbrueckii subsp bulgaricus en culture pure et en coculture.

$\mathrm{Vm}, \mathrm{pHm}$ and $\mathrm{Tm}$ values estimated by $\mathrm{pH}$ kinetics in milk $\left(42^{\circ} \mathrm{C}\right)$ for $\mathrm{S}$ salivarius subsp thermophilus and $\mathrm{L}$ delbrueckii subsp bulgaricus strains in pure and mixed culture.

\begin{tabular}{|c|c|c|c|c|c|c|c|}
\hline $\begin{array}{l}\text { Souche } \\
\text { ( } N^{\circ} \mathrm{C} N R Z \text { ) }\end{array}$ & $\begin{array}{c}V m_{1} \\
\left(m \cup p H \text { min }^{-1}\right)\end{array}$ & $\begin{array}{c}V m_{2} \\
\left(m U p H^{-1} \min ^{-1}\right)\end{array}$ & $p H m_{1}$ & $\mathrm{pH} \mathrm{m}_{2}$ & $\begin{array}{l}T m_{1} \\
(\min )\end{array}$ & $\begin{array}{l}\mathrm{Tm}_{2} \\
\text { (min) }\end{array}$ & $\begin{array}{l}d T m \\
\text { (min) }\end{array}$ \\
\hline $1187^{*}$ & 6,7 & & 5,83 & & 132 & & \\
\hline 1197 & 6,6 & 4,7 & 6,12 & 5,82 & 69 & 166 & 97 \\
\hline \multirow[t]{2}{*}{$1197 / 1187$} & 6,5 & 5,3 & 6,36 & 5,73 & 81 & 183 & 102 \\
\hline & 6,8 & 4,5 & 6,03 & 5,74 & 81 & 184 & 103 \\
\hline 1156 & 7,6 & 8,1 & 6,07 & 5,67 & 53 & 128 & 75 \\
\hline \multirow{2}{*}{$1156 / 1187$} & 8,0 & 7,2 & 6,05 & 5,90 & 64 & 175 & 111 \\
\hline & 8,0 & 10,6 & 6,06 & 5,55 & 62 & 160 & 98 \\
\hline 1157 & 5,9 & 6,8 & 6,21 & 5,87 & 98 & 168 & 70 \\
\hline \multirow[t]{2}{*}{$1157 / 1187$} & 5,9 & 4,6 & 6,15 & 5,85 & 92 & 189 & 97 \\
\hline & 5,5 & 4,6 & 6,07 & 5,74 & 93 & 196 & 103 \\
\hline 1203 & 7,0 & 4,3 & 6,00 & 5,73 & 74 & 176 & 102 \\
\hline \multirow{2}{*}{$1203 / 1187$} & 6,5 & 4,1 & 5,98 & 5,73 & 75 & 188 & 113 \\
\hline & 6,2 & 3,8 & 6,07 & 5,68 & 73 & 215 & 142 \\
\hline 1209 & 6,1 & 14,6 & 6,07 & 5,66 & 63 & 117 & 54 \\
\hline \multirow[t]{2}{*}{$1209 / 1187$} & 4,7 & 8,0 & 6,13 & 5,73 & 60 & 157 & 97 \\
\hline & 4,9 & 8,2 & 6,07 & 5,50 & 65 & 179 & 114 \\
\hline
\end{tabular}

* Le lactobacille CNRZ 1187 ayant une seule vitesse d'acidification maximale, les valeurs des paramètres Vm, $\mathrm{HHm}$ et $\mathrm{Tm}$ sont arbitrairement placées comme $\mathrm{Vm}, \mathrm{pH}$, et $\mathrm{Tm}$, respectivement.

- As lactobacillus CNRZ 1187 has only one maximum acidification rate, $\mathrm{Vm}, \mathrm{pHm}$ and $\mathrm{Tm}$ values are therefore arbitrarily given as $\mathrm{Vm}_{1}, \mathrm{pHm}_{1}$ and $\mathrm{Tm}_{1}$ respectively.

fiante est un important critère de sélection, à la fois pour la fabrication des laits fermentés et pour la fromagerie (Accolas et al, 1980; Kurmann, 1983; Chamba et Prost, 1989). À cet égard, deux groupes de lactobacilles sont mis en évidence dans la présente étude. Les souches du premier groupe, qui ont de faibles valeurs de $\mathrm{Vm}$, développent des acidités titrables élevées. Celles du second ont des valeurs de $\mathrm{Vm}$ élevées et développent des acidités titrables en général plus faibles. La prise en considération des valeurs de T50 montre en effet que la phase d'acidification intense (vitesse d'acidification supérieure à $\mathrm{Vm} / 2$ ) est plus longue, et conduit à une produc- tion d'acide plus élevée. La corrélation étroite entre $V m$ et $T 50$, caractérise les lactobacilles comme les streptocoques (Zourari et al, 1991). Elle a été également observée par Spinnler et Corrieu (1989). Cela pourrait résulter de la sensibilité des bactéries à une quantité donnée d'acide lactique, qui est produit en un temps plus court quand $V m$ est plus élevée.

L'acidification du lait permet aussi de mettre en évidence la synergie existant entre les deux germes en culture mixte. Elle est donc un critère de sélection des paires de souches, pour la fabrication du yaourt (Kurmann, 1983). La stimulation n'est pas évidente au début de la crois- 

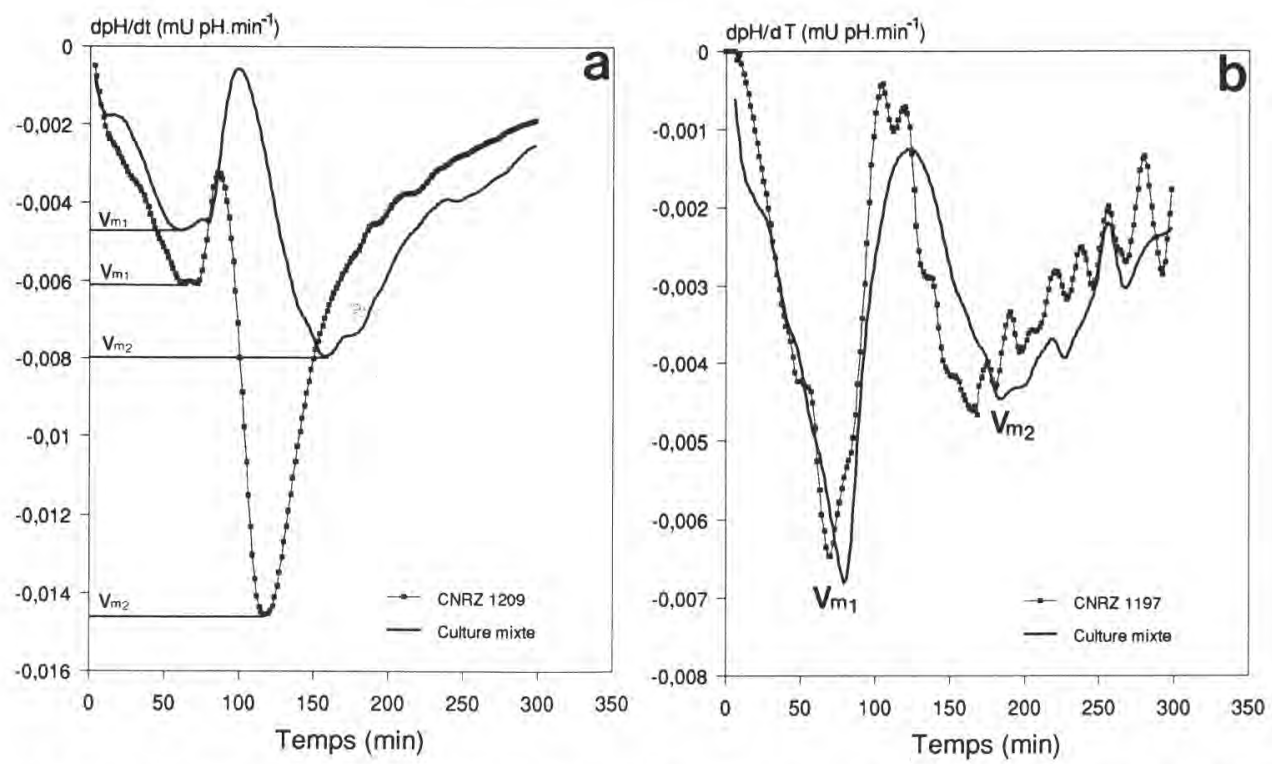

Fig 8. Évolution de la vitesse d'acidification (dpH/dt) au cours de la croissance dans le lait $\left(42^{\circ} \mathrm{C}\right)$ pour les souches $S$ salivarius subsp thermophilus CNRZ 1209 (a) et CNRZ 1197 (b) en culture pure et en coculture avec la souche $L$ delbrueckii subsp bulgaricus CNRZ 1187.

Acidification rate kinetics (dpH/dt) during growth in milk for $\mathrm{S}$ salivarius subsp thermophilus CNRZ 1209 (a) and CNRZ 1197 (b) in pure culture and associated with L delbrueckii subsp bulgaricus CNRZ 1187.

sance, car le streptocoque est alors le principal responsable de la production d'acide. Par la suite, la production active d'acide par le lactobacille commence et, quand il y a une stimulation, l'acidité titrable de la culture mixte est nettement supérieure à la somme des acidités obtenues en culture pure par les deux souches, comme dans les cas cités le plus souvent dans la littérature (Pette et Lolkema, 1950; Bautista et al, 1966; Moon et Reinbold, 1976; Accolas et al, 1980).

L'association du lactobacille CNRZ 1187 avec les streptocoques CNRZ 1197 et 1203 n'entraîne pas de stimulation de la production d'acide. Des cas analogues ont déjà été observés. Ils résulteraient de la compétition pour un substrat indispen- sable, par exemple les nutriments azotés (comme il a été observé pour des cultures associées de lactocoques par Juillard et Richard, 1989), ou de la production d'agents antibactériens par l'une des souches (Pette et Lolkema, 1950; Moon et Reinbold, 1974). Néanmoins, puisque l'équilibre des deux populations est influencé par de nombreux facteurs, par exemple la température (Accolas et al, 1977), l'absence de synergie pourrait tout aussi bien résulter du déséquilibre de la croissance des deux germes, suite à une proportion inadéquate dans l'inoculum (Pette et Lolkema, 1950), ou à des vitesses de croissance très différentes qui conduiraient à la production réduite des facteurs responsables de la stimulation. À ce propos, il 
faut rappeler que, dans notre étude, il s'agit de deux streptocoques dont la croissance et l'acidification dans le lait sont lentes, en particulier dans le cas de la souche CNRZ 1203. Ce streptocoque se caractérise en effet par une activité uréasique très faible, qui pourrait expliquer l'absence de stimulation, faute d'une production très faible de $\mathrm{CO}_{2}$ connu pour son effet stimulant sur la croissance du lactobacille (Driessen et al, 1982).

Si l'on considère les vitesses d'acidification, l'interprétation des résultats se complique. Spinnler et Corrieu (1989) ont observé en culture mixte des valeurs de Vm supérieures à celles estimées en culture pure, sans toutefois s'attarder sur l'interprétation des deux $V m$ caractérisant le streptocoque qu'ils retrouvent en coculture. Dans le présent travail, l'évolution du $\mathrm{pH}$ et de la vitesse d'acidification en culture mixte confirment les observations basées sur l'acidité titrable. Dans quatre cas sur les cinq étudiés, la valeur de $V m_{1}$ est identique à celle du streptocoque seul. Cela confirme à l'évidence que le streptocoque assure seul, pour l'essentiel, l'acidification au début de la coculture. La valeur de $\mathrm{Vm}_{2}$ dépend à la fois de l'activité uréasique du streptocoque et de la stimulation de son acidification. Dans le cas de la souche 1203 , qui a l'activité uréasique la plus faible et ne montre pas de synergie en coculture, les valeurs de $V m_{2}$ sont identiques en culture pure et en association. En ce qui concerne la souche 1209, qui acidifie bien et qui a l'activité uréasique la plus forte, la valeur de $V m_{2}$ en culture mixte est bien inférieure à celle mesurée en culture pure. Cette observation suggère l'hypothèse d'une stimulation éventuelle de l'activité uréasique du streptocoque en coculture, qui reste à confirmer. Le suivi automatique du $\mathrm{pH}$ permet donc d'expliquer le comportement des souches en culture mixte. L'interprétation nécessite beau- coup d'attention, mais il est possible d'obtenir ainsi plus de renseignements qu'en se basant uniquement sur l'acidité titrable.

La quantité d'acétaldéhyde produite par les souches de lactobacilles est beaucoup plus importante (environ le double) de celle produite par les streptocoques (Zourari et al, 1991), comme cela a déjà été observé dans la littérature (Bottazzi et Dellaglio, 1967; Hamdan et al, 1971; Bouillanne et Desmazeaud, 1981). Par exemple, 28 souches de $L$ delbrueckii subsp bulgaricus fraîchement isolées de yaourts, sur les 84 étudiées par Bottazzi et Vescovo (1969), produisaient plus de 6,5 ppm d'acétaldéhyde. Une stimulation de la production d'acétaldéhyde en culture mixte n'est pas mise en évidence dans le présent travail. La quantité produite demeure équivalente à celle du lactobacille seul, contrairement à ce qu'avaient observé Hamdan et al (1971).

Les mesures de la viscosité du lait coagulé mettent en évidence le caractère épaississant des souches, mais elles sont influencées par de nombreux facteurs, notamment le traitement thermique du lait. La réalisation des mesures de viscosité à une valeur de $\mathrm{pH}$ donnée permettent de standardiser les conditions physico-chimiques du milieu, et de maintenir constante la viscosité due à la précipitation des protéines et aux interactions des composés du lait. Bouillanne et Desmazeaud (1980, 1981) ont trouvé un nombre important de souches épaississantes. Cela peut s'expliquer par le fait que beaucoup de leurs souches provenaient de levains à yaourt ou de yaourts industriels français, et avaient été intentionnellement sélectionnées sur ce critère par les fabricants de yaourt. II n'en va pas de même pour les souches de la présente étude, qui proviennent de yaourts artisanaux, c'est-à-dire d'un type de fabrication où le caractère épaississant n'est pas pris en compte pour 
une sélection méthodique des souches. De plus, il faut retenir qu'en Grèce, le yaourt artisanal est souvent fabriqué avec du lait de brebis, qui donne au produit une texture plus épaisse que le lait de vache.

Les trois souches épaississantes mises en évidence ne possèdent pas de plasmides (Zourari, 1991). Par conséquent, le caractère épaississant ne peut pas être corrélé, dans ce cas, à la présence de plasmides. À cet égard, la situation est donc différente de celle qu'on a observé dans le cas de $L$ casei subsp casei (Vescovo et al, 1989) et dans celui des lactocoques (Vedamuthu et Neville, 1986).

La coculture n'a pas d'effet sur le caractère épaississant, sinon que l'apparition d'une viscosité élevée est retardée et correspond à des $\mathrm{pH}$ plus acides, en raison de la croissance tardive du lactobacille. Cela va donc dans le sens des observations de Galesloot et Hassings (1973), qui ont associé différentes souches de streptocoques et de lactobacilles, épaississantes ou non, sans obtenir d'effet de synergie sur le plan de la viscosité. Cependant, Cerning et al (1988) ont associé une souche de $S$ salivarius subsp thermophilus épaississante et une souche de L delbrueckii subsp bulgaricus non épaississante. La viscosité et la production de polysaccharide étaient trois fois plus élevées dans la culture mixte que dans la culture pure du streptocoque. Une telle stimulation n'est pas observée dans le cas de la souche CNRZ 1187. II apparaît ainsi que selon les souches utilisées, l'évolution de la viscosité en coculture peut considérablement varier.

Au cours de la conservation à basse température, les caractères organoleptiques du yaourt peuvent être modifiés, suite surtout à une acidification supplémentaire (post-acidification) qui dépend de l'espèce, puisque seuls les lactobacilles abaissent notablement le $\mathrm{pH}$ (Zourari et al,
1991), mais aussi de la souche et des conditions de conservation. Ces résultats sont analogues à ceux qui sont cités dans la littérature (Accolas et al, 1977; Kurmann, 1983). Parallèlement, une chute de la quantité d'acétaldéhyde est observée à base température, en culture pure comme en coculture. Elle est apparemment indépendante des souches utilisées (Hamdan et al, 1971; Tealdo et al, 1989; Zourari et al, 1991).

En ce qui concerne la comparaison des souches sur la base de tous les caractères, des groupes bien différenciés de lactobacilles sont établis, à la différence des streptocoques étudiés précédemment (Zourari et al, 1991). Une moindre propension à la diversité des souches de lactobacilles examinées est donc ainsi révélée. II est vrai que les souches les plus proches ont été isolées du même échantillon de yaourt (tableau I). II serait donc logique de penser qu'il s'agissait d'isolats de la même souche. Nous les avons cependant conservées dans la présentation du travail, puisque notre objectif était de valoriser les méthodes d'analyse des données utilisées, par la mise en évidence non seulement de la diversité des souches, mais aussi de leurs similarités.

\section{REMERCIEMENTS}

Le présent travail a bénéficié d'un financement de la Communauté Économique Européenne (Programme BAP-CEE N0144F). Nous remercions G Corrieu (LGPBA, INRA, Grignon), $S$ Roger, C Bouillanne, J Cerning (Station de recherches laitières, INRA, Jouy-en-Josas) et J Carvallo Garcia (Université de Léon, Espagne) pour leur précieuse collaboration au cours du travail expérimental. Nous remercions également C Chabanet (Station de Biométrie, INRA, Jouy-en-Josas) de sa participation à l'analyse des données et JP Accolas pour sa lecture critique d'une des versions de cet article. 


\section{RÉFÉRENCES}

Accolas JP, Bloquel R, Didienne R, Régnier J (1977) Propriétés acidifiantes des bactéries lactiques thermophiles en relation avec la fabrication du yoghourt. Lait 67, 1-23

Accolas JP, Hemme D, Desmazeaud MJ, Vassal L, Bouillanne C, Veaux M (1980) Les levains lactiques thermophiles : propriétés et comportement en technologie laitière. Une revue. Lait 60, 487-524

Anonyme (1983) Influence sur la santé d'une alimentation avec des produits laitiers contenant des cultures de microorganismes. Bull Féd Int Lait 159, 20-32

Bautista ES, Dahiya RS, Speck ML (1966) Identification of compounds causing symbiotic growth of Streptococcus thermophilus and Lactobacillus bulgaricus in milk. J Dairy Res 33, 299-307

Bottazzi V, Dellaglio F (1967) Acetaldehyde and diacetyl production by Streptococcus thermophilus and other lactic streptococci. J Dairy Res 34, 109-113

Bottazzi V, Vescovo M (1969) Carbonyl compounds produced by yoghurt bacteria. Neth Milk Dairy J 23, 71-78

Bouillanne C, Desmazeaud MJ (1980) Étude de quelques caractères de souches de Streptococcus thermophilus utilisées en fabrication de yoghurt et proposition d'une méthode de classement. Lait 60, 458-473

Bouillanne C, Desmazeaud MJ (1981) Classement de souches de Lactobacillus bulgaricus selon quelques caractères utilisés en fabrication du yoghurt. Association avec Streptococcus thermophilus. Sci Aliments 1, 7-17

Cerning J, Bouillanne C, Desmazeaud MJ, Landon $M$ (1986) Isolation and characterization of exocellular polysaccharide produced by Lactobacillus bulgaricus. Biotechnol Lett 8 , 625-628

Cerning J, Bouillanne C, Desmazeaud MJ, Landon M (1988) Exocellular polysaccharide production by Streptococcus thermophilus. Biotechnol Lett 10, 255-260

Chamba JF, Prost F (1989) Mesure de l'activité acidifiante des bactéries lactiques thermophiles utilisées pour la fabrication des fromages à pâte cuite. Lait $69,417-423$
Desmazeaud MJ, Hermier JH (1973) Effet des fragments peptidiques du glucagon vis-à-vis de la croissance de Streptococcus thermophilus. Biochimie 55, 679-684

Driessen FM, Kingma F, Stadhouders J (1982) Evidence that Lactobacillus bulgaricus in yogurt is stimulated by carbon dioxide produced by Streptococcus thermophilus. Neth Milk Dairy J 36, 135-144

Galesloot TE, Hassing F (1973) Further investigations concerning the consistency of yoghurt. NIZO Mededelingen $\mathrm{Nr} 7,15-33$

Galesloot TE, Hassing F, Veringa HA (1968) Symbiosis in yoghurt (I). Stimulation of Lactobacillus bulgaricus by a factor produced by Streptococcus thermophilus. Neth Milk Dairy $J 22,50-63$

Hamdan IY, Kunsman JE Jr, Deane DD (1971) Acetaldehyde production by combined yogurt cultures. J Dairy Sci 54, 1080-1082

Higashio K, Kikuchi T, Furuichi E (1978) Symbiose entre Lactobacillus bulgaricus et Streptococcus thermophilus dans le yoghourt. $X X^{\theta}$ Congr Int Lait, Brèves Commun (F), 522-523

Juillard V, Richard J (1989) Étude de l'interaction entre souches protéolytiques de streptocoques lactiques mésophiles et leurs variants non protéolytiques, au cours de leur croissance dans le lait. Lait 69, 291-304

Kurmann JA (1983) Die Joghurkultur, deren Selektion auf die Produktionseigneschaften im Betriebslaboratorium und deren gärungstechnischer Einsatz in der Joghurt-Fabrikation. Dtsch Milchwirtsch 20, 658-660

Lees GJ, Jago GR (1976) Formation of acetaldehyde from threonine by lactic acid bacteria. J Dairy Res $43,75-83$

Manca De Nadra MC, Raya RR, Pesce De Ruiz Holgado A, Oliver G (1987) Isolation and properties of threonine aldolase of Lactobacillus bulgaricus $\mathrm{YOP}_{12}$. Milchwissenschaft 42, 9294

Moon NJ, Reinbold GW (1974) Selection of active and compatible starters for yogurt. Cult Dairy Prod J 9, 10-12

Moon NJ, Reinbold GW (1976) Commensalism and competition in mixed cultures of Lactobacillus bulgaricus and Streptococcus thermophilus. J Milk Food Technol 39, 337-341 
Pereira Martins JF, Luchese RH (1988) Determination of compatibility in associated growth between strains of Lactobacillus bulgaricus and Streptococcus thermophilus. Rev Inst Lactic Cândido Tostes 43, 11-13

Pette JW, Lolkema H (1950) Yoghurt. I. Symbiosis and antibiosis in mixed cultures of $L b$ bulgaricus and Sc thermophilus. Neth Milk Dairy $J 4,197-208$

Shankar PA, Davies FL (1978) Relation entre Steptococcus thermophilus et Lactobacillus bulgaricus dans les levains du yoghourt. $X X^{e}$ Congr Int Lait, Brèves Commun ( $F$ ), 521-522

Sharf JM (1966) Recommended methods for the microbiological examination of foods 2 nd edn. American Public Health Association Inc, New York

Spinnler HE, Corrieu G (1989) Automatic method to quantify starter activity based on $\mathrm{pH}$ measurement. J Dairy Res 56, 755-764

Tealdo E, Tutta C, Barcarolo R, Castioni R, Faccin M, Fellin A, Gaburro L, Tapparo M (1989) Physico-chemical and organoleptic characterization of yogurt. Latte 14, 153-161
Vedamuthu ER, Neville JM (1986) Involvement of a plasmid in production of ropiness (mucoidness) in milk cultures by Streptococcus cremoris MS. Appl Environ Microbiol 51, 677682

Veringa HA, Galesloot TE, Davelaar H (1968) Symbiosis in yoghurt. II. Isolation and identification of a growth factor for Lactobacillus bulgaricus produced by Streptococcus thermophilus. Neth Milk Dairy J 22, 114-120

Vescovo M, Scolari GL, Bottazzi V (1989) Plasmid-encoded ropiness production in Lactobacillus casei ssp casei. Biotechnol Lett 11, 709-712

Zourari A (1991) Caractérisation de bactéries lactiques thermophiles isolées à partir de yaourts artisanaux grecs. Thèse de Doctorat, INA-Paris-Grignon, France

Zourari A, Roger S, Chabanet C, Desmazeaud MJ (1991) Caractérisation de bactéries lactiques thermophiles isolées de yaourts artisanaux grecs. I. Souches de Streptococcus salivarius subsp thermophilus. Lait 71, 445-461 